\title{
Innovation in Education: the Social Sciences Teaching Materials Development to Encourage Students' Culture- Based Intelligence at SMP N 8 of Surakarta

\author{
${ }^{1 \text { st }}$ Vidia Ulfa \\ Mareta \\ Master Program in \\ Educational \\ Technology, Sebelas \\ Maret University
}

\author{
${ }^{2 n d}$ Prof. Sunardi, M. \\ Sc. \\ Lecturer of \\ Educational \\ Maret University
} \\ Technology, Sebelas

\author{
${ }^{3 r d}$ Dr. Suharno, M. \\ Pd. \\ Lecturer of \\ Educational \\ Technology, Sebelas \\ Maret University
}

\author{
${ }^{4 \text { th }}$ Hermia Anata \\ Rahman
}

\author{
Master Program in \\ Educational \\ Technology, Sebelas \\ Maret University
}

\begin{abstract}
Technology is currently growing rapidly over time and demands changes in various fields. One of the expected changes is in the field of education. Changes in education are needed to improve the quality of education. Education as a developer of human resources (HR), should always experience changes in a better direction. Teaching materials used as transfer of knowledge in schools also need to be developed, so that they seem more modern. Moreover, in social studies subjects that have a lot of material so that more modern teaching materials should be developed, in this case to improve culture-based intelligence. This research aims to improve student's culture-based intelligence through the development of teaching materials on social science material for students of SMP N 8 Surakarta. The research was carried out in the odd semester 2018-2019. The method used is R \& D with the Control Group Design Pretest-posttest research design. The research population was 7 th grade students. The sample is assigned class $7 \mathrm{H}$ as the experimental class and 7G as the control class. The instrument in this research is a questionnaire. Data were analyzed descriptively. The result of research showed that culture-based intelligence of students through the development of social learning materials on social interaction material with very good categories. Based on the results of research, it can be concluded that the development of social studies teaching materials can improve the cultural intelligence of students at SMP N 8 of Surakarta.
\end{abstract}

Keywords: Social Teaching Materials, Social Science, CultureBased intelligence

\section{INTRODUCTION}

Social Sciences (IPS) as an integrated subject, consists of various social sciences disciplines and is taught in an integrated manner. IPS is a KTSP structure in primary and secondary education, especially on Social Sciences subject was implemented not as a separate subject, consists of other disciplines ranging from economics, sociology, history, to geography. Similarly, E. Mulyasa (2007) emphasized that the second point of curriculum structure on Junior High School (SMP / MTs) is that the substance of social studies subject introduced to this level should be "an Integrated Social Sciences /IPS". As was mandated by KTSP, that IPS is implemented as an integrated subject from various social science disciplines.

Concerning the expected social sciences (IPS) learning to be implemented in an integrated manner, there is a remaining confusion on both teachers and students regarding the integrated model of IPS. The reference books have not yet referred to the integrated social sciences, these books are even partly embeded in other subjects such as geography, economics, history, and sociology. That is why, the integrated aspects will last neglected. In fact, in case the material is presented separately in those fields of study, there will be new introducing theories and concepts which turn finally turn the students into having difficulty in comprehending the social sciences subject at junior high school level.

Teaching material is one of the learning sources. Teaching material covers a lot of materials that enable assisting teachers in undertaking teaching and learning activities. Teaching materials can either be written or unwritten materials. The most commonly used teaching materials by teachers are the printed one, which is students'books of exercise (LKS). The typical books mostly used by teachers are the Electronic School Books, available and provided as a government project. These books are accessible and ready to use, because of that, teachers feel that they do not anymore need to compile teaching material on their own. There are remaining few teachers who attempt to apply diverse learning resources or develop the existing learning resources. Meanwhile, if 
only these teachers would apply a diverse learning resources, it will be easier for students to understand the given materials.

Teaching materials are highly needed in teaching and learning process. To review this from the outline point of view, the teaching material are loaded with contents, which substance includes knowledge (facts, concepts, principles, and procedures), skills, and attitudes (values). By having a well-prepared teaching materials, we shall have an extensive knowledge. In any learning process, it is insufficient to use a single teaching material. Teachers ought to use several teaching materials to increase students' knowledge. Moreover, an interesting teaching material equally increases students' learning interest.

Based on an interview data conducted on Friday, August 10, 2018 with Ibu Murni, S.Pd., as a social sciences teacher at the State Junior High School SMPN 8 of Surakarta. The interview discussed the learning conducted to students classroom of grade VII ,especially on a social science subject, she informed that the learning was carried out using printed teaching materials, popularly known the Electronic School Books. Teaching materials from books provided by government are considered practical and easy to use within a teaching-learning process. Accordingly, the social science learning activities have never been integrated with the existing teaching materials. Based on the results of interviewing classroom teachers, a conclusion could be made. In teaching-learning activities, the teachers applied materials from books provided by government, and without necessarily need additional learning resources. Nearly all teachers have never developed the already provided teaching materials, especially the Electronic School Books.

The potential of among the schools lay on those provided guiding books to assist teachers in conducting learning process, which is the Electronic School Books. However, the arising problems out of the limitations of learning resources shall have an impact on the teachers' perceptions of not going to necessarily use other learning resources and have never developed the ideal teaching materials. The development of teaching materials is carried out to complement the shortcomings of printed Electronic School Books materials. The displayed pictures and materials should be appropriate and complete. Developing teaching material in grade VII students is undoubtly important matter. This is because in conducting any learning activity, it requires a lot of learning resources, more importantly in regard of the social science material which typically covers a wide range of disciplinary. Students will be more easily understand the given material with a variety of learning resources. Therefore, it is necessary to develop teaching materials out of the culturebased intelligence of Electronic School Books.

Culture-based intelligence is conceptualized as a specific embodiment of intelligence focusing on an individual's ability to both understand and share correct reasons within a situated cultural diversity. Similarly, on emotional intelligence (EQ) which presence is to complements the cognitive intelligence (IQ), both are an integrated ability directing individuals to gain their success in the workplace and in personal relationships in an increasingly interdependent world (Earley \& Gibson, 2002). The culture-based intelligence is another form that complements the intelligence, which can help explaining variability in dealing with diversity and function in the new cultural settings. Bearing in mind, the norms of social interaction vary from culture to culture, it is impossible for cognitive intelligence, emotional intelligence, or social intelligence being automatically transmitted into effective cross-cultural adjustments and interactions (Ang et al, 2008).

Integrating the various experts' views on intelligence, Sternberg and Detterman (1986) suggested that intelligence is at the indifferent locus within individuals, which include the biology, cognition (including metacognition), motivation, and behavior. Having inspired by Sternberg \& Detterman's view, Earley and Ang (2003) constructed a model of culture-based intelligence which consists of four major dimensions: (1) metacognitive of culture-based intelligence reflects the individuals' mental ability in both obtaining and understanding of the cultural knowledge; (2) cognitive culture-based intelligence reflects individuals' knowledge on culture and cultural differences; (3) culture-based intelligence of motivation reflects the individuals' ability to direct and maintain business towards functioning within the intercultural situations; and (4) culture-based intelligence behavior reflects individual's ability to be flexible within their cross-cultural interactions. These four major dimensions can be improved through training, exploring more experience, and education. Therefore, culture-based intelligence focuses on developing a global theoretical framework to identify and understand the needed of cultural skills, knowledge, and behaviors to effectively function within the culturally diverse societies.

The development of this teaching material is the printed one, which is a cultural intelligence-based textbook for classroom students of grade VII. The applied material was social interaction. The development of this teaching material needs to be undertaken to partly enrich the learning resources in students' classroom of grade VII, additionally it will help teachers to participate in developing the teaching materials. It is expected that teachers will be more creative and intentionally create the teaching materials more attractive, therefore, the students can be more enthusiastic in enjoying the classroom learning process, and which partly can improve the students' cultural intelligence.

\section{METHODS}

Research place and time

This study was carried out to students of the State Junior High School (SMP) of 8 Surakarta, in the odd semester of the $2018 / 2019$ school year.

Research Instruments 
This study applied research instrument in a questionnaire form which is an assessment tool used to measure students' cultural intelligence.

\section{Population and Sample}

The population in this study were all the VII grade students at the State Junior High School (SMP) of 8 Surakarta, whereas the research sample in this study was the VII grade students specifically the H classroom, they were devided into 30 students as experimental class and VII grade students of $\mathrm{G}$ classroom consists of 30 students as the control class.

\section{Research design}

The research design applied the Pre-posttest Control Group Design. The experimental class carried out teaching and learning activities using the social science teaching materials on culture-based intelligence. Meanwhile, the learning control class applied the common use of electronic books.

Data Analysis of Questionnaire Assesment

The rating scale was ranged from 1 to 5 . The interpretation of these numbers is: 1 = very less, $2=$ less, $3=$ average, 4 $=$ good and $5=$ very good. To seek out the students' cultural intelligence, the following formula was used:

$$
\begin{aligned}
& \text { Nilai } \frac{\text { Skor Total Peserta Didik }}{\text { Skor Maksimal }} \times 100 \\
& \text { (Suwandi, 2011) }
\end{aligned}
$$

The criteria labelling the assessment scores on students' performance following Arikunto's model (2007) as illustrated in below table 1 .

Table 1. Criteria labelling the Questionnaire Assessment of

\begin{tabular}{|c|c|c|}
\hline \multicolumn{2}{|c|}{ Nilai } & \multirow{2}{*}{ Kategori } \\
\hline Angka & Huruf & \\
\hline $81-100$ & $\mathrm{~A}$ & Sangat Baik \\
\hline $61-80$ & B & Baik \\
\hline $41-60$ & $\mathrm{C}$ & Cukup \\
\hline $21-40$ & D & Kurang \\
\hline $0-20$ & E & Sangat Kurang \\
\hline
\end{tabular}
Culture-based Intelligence

III. RESULTS AND DISCUSSION

The results of data analysis are presented in two graphs, namely the assessment diagram to signify the experimental class which carried out teaching and learning activities using social science teaching materials on culture-based intelligence. While the second graph is an assessment for learning control classes through the use of common electronic books. Among the aspects of culture-based intelligence include 4 dimensions, namely CI Metacognitive, CI Cognitive, CI Motivation, and CI Behavior.

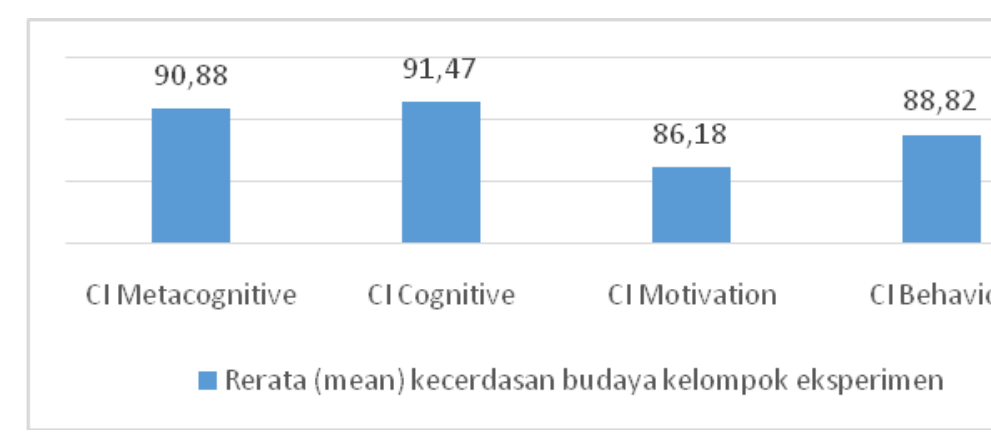

Figure 1. Culture-based Intelligence Percentage on the Experimental Groups

On Figure 1, the students' cultural intelligence of the experimental group on the Cognitive CI dimension had the highest mean of 91.47 then followed by CI Metacognitive as much as 90.88, CI Behavior 88.82 and the lowest was CI Motivation showing 86.18.

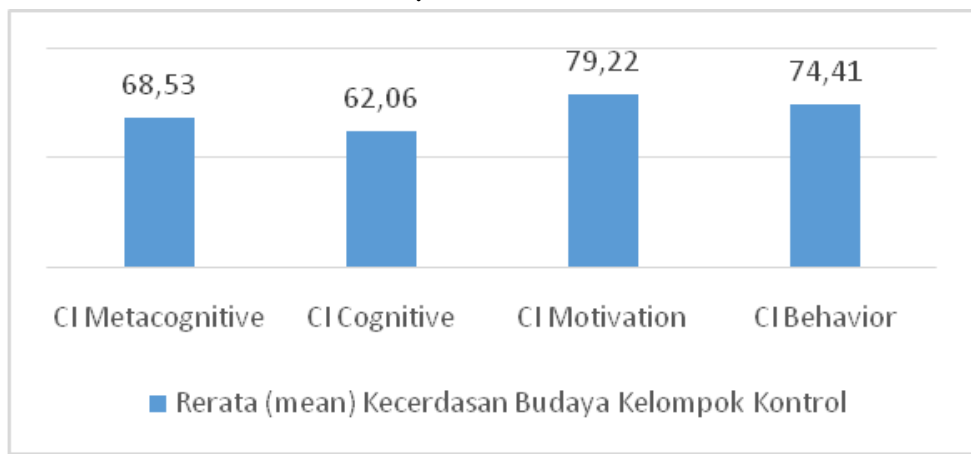

Figure 2. Control Group Percentage on Culture-based Intelligence

On Figure 2, the culture-based intelligence of students in control group on the dimension of CI Motivation reflects the highest mean score of 79.22 followed by CI Behavior with 74.41, CI Metacognitive 68.53 and the lowest is the Cognitive CI with 62.06.

Based on these two presented graphs, a conclusion can be derived. The experimental group students' intelligence was tested by using social science teaching materials on culture-based intelligence has a higher mean value compared to students' intelligence control group. The experimental group had the highest mean on the CI Cognitive dimension, then CI Metacognitive, CI Behavior, and the lowest is the CI Motivation. This result can be explained in the following description:

Cognitive CI dimension showed the highest mean in this study. The cognitive dimensions were defined as knowledge of the cultural aspects of the environment and one's residence in it, and broadly encompasses universal culture and cultural differences (Ang et al., 2007). Students are quite knowledgeable about culture, including values, norms, and environment.

The CI Metacognitive dimention showed the second highest mean score, which means students have both consciousness and ability in setting up strategies to 
succeed in multicultural interaction. They are able to change both understanding and behavior within the crosscultural interaction as was triggered by the shifting information and environment. As a trait, metacognitive characteristics share similarity with Sue and Torino's conceptual model of multicultural consciousness (2005).

The next is the CI Behavior dimension. In a broad conceptual sense, the behavioral dimension reflects skill components of the multicultural competence. Sue \& Sue (2003) described significant multicultural counseling skills for these would combine between the culturally-deemed appropriate verbal and nonverbal responses, sustain the institutional changes which represent counselees and adapt to counselee's role of expectations.

The CI Motivation dimension was at the lowest position, which means that students share sufficient motivation in interacting within their multicultural situations. The motivational dimension reflects the intrinsic ability of individuals to seeking and enjoying interaction with people of diverse cultures on a consistent basis. Involving motivation in multicultural counseling is not explicitly handled by the multicultural counseling competency model of Sue et al (1982).

\section{CONCLUSIONS}

Based on the results of the study, a conclusion can be derived that the use of social consciousness-based social science teaching materials on social interaction material can improve students' culture- based intelligence of grade VII at the State Junior High School (SMPN) 8 of Surakarta.

\section{References}

Ang, S., Van Dyne, L., Koh, C., Ng, K.-Y., Templer, K. J., Tay, C., \& Chandrasekar, N. A. (2007). Cultural intelligence: Its measurement and effects on cultural judgment and decision making, cultural adaptation and task performance. Management and Organization Review, 3, 335-371. doi:10.1111/j.1740-8784.2007.00082.x.

Arikunto, S., 2007, Prosedur Penelitian Suatu Pendekatan Praktek Edisi Revisi VI, Rineka Apta. Jakarta.

Mulyasa, E. 2007. Kuriklum tingkat satuan pendidikan sebuahpanduan praktis. Bandung: PT Remaja Rosdakarya.

Sternberg, R. J., \& Detterrnan, D. K. (1986). What is intelligence? .Norwood, NJ: Ablex.

Sue DW, Bernier JB, Duran M, Feinberg L, Pedersen P, et al. Position paper: cross-cultural counseling competencies. Couns. Psychol 1982;10(2):45-52. Presents issues that later deeply influenced the multicultural guidelines adopted by the American Psychological Association.

Sue DW, Bernier JB, Duran M, Feinberg L, Pedersen P, et al. Position paper: cross-cultural counseling competencies. Couns. Psychol 1982;10(2):45-52. Presents issues that later deeply influenced the multicultural guidelines adopted by the American Psychological Association.

Sue, DW.; Torino, GC. Racial-cultural competence: awareness, knowledge, and skills. In: Carter, RT., editor. Handbook of Racial-Cultural Psychology and Counseling: Training and Practice. Vol. Vol.2. Hoboken, NJ: Wiley; 2005. p. 3-18

Suwandi, Joko. 2011. Penelitian Tindakan Kelas. Surakarta : Universitas Muhammadiyah Surakarta.

Van Dyne, L., Ang, S., \& Koh, C. (2008). Development and validation of the CQS: The cultural intelligence scale. In S. Ang \& L. Van Dyne (Eds.), Handbook of cultural intelligence: Theory, measurement, and applications (pp. 1638). New York, NY: Sharpe.

Earley PC and Gibson CB. (2002). Multinational Work Teams (Lawrence Erlbaum Associates, Mahwah, $\mathrm{NJ})$.

Earley, P.C., \& Ang, S. (2003). Cultural intelligence. Stanford, CA: Stanford University Press. 